\title{
Conception rate with or without hCG trigger in clomiphene induced cycles
}

\author{
Aruna Verma*, Abhilasha Gupta, Monika Kashyap, Juveriya Meraj
}

Department of Obstetrics and Gynecology, LLRM Medical College, Meerut, Uttar Pradesh, India

Received: 14 June 2021

Accepted: 09 July 2021

\section{*Correspondence:}

Dr. Aruna Verma,

E-mail: arunaverma36@gmail.com

Copyright: () the author(s), publisher and licensee Medip Academy. This is an open-access article distributed under the terms of the Creative Commons Attribution Non-Commercial License, which permits unrestricted non-commercial use, distribution, and reproduction in any medium, provided the original work is properly cited.

\section{ABSTRACT}

Background: Clomiphene citrate (CC) is still the most common drug for ovulation induction. Most physicians use hCG trigger routinely for follicle rupture. Ideally hCG is recommended only where there is no spontaneous LH surge. Hence this study was conducted to see the role of hCG for follicle rupture in CC induced cycle. Aims and objectives of the study were to compare the ovulation rate in $\mathrm{CC}$ induced cycle with or without hCG trigger and finally the conception rate.

Methods: Study was conducted in the department of OBG, LLRM medical college Meerut on women with anovulatory infertility. All women were given 50-100 mg CC. Follicular study from D-9 was done till follicle rupture. Women in group A were observed without any trigger and women in group B were given inj. hCG trigger 10,000 IU when follicle size reached $20-22 \mathrm{~mm}$.

Results: Conception rates were $25 \%$ Vs $31 \%$ in group A and group B. Follicle rupture was seen in $84 \%$ cases in group A and $71 \%$ in group B. Results were comparable in both the groups.

Conclusions: By adding inj. hCG for ovulation trigger does not increase the conception rate. LH surge is already there in $\mathrm{CC}$ induced cycles. It is having role only in cases where no $\mathrm{LH}$ surge is there.

Keywords: HCG trigger, Clomiphene citrate, Anovulatory infertility

\section{INTRODUCTION}

Infertility is encountered in about $5-10 \%$ of cases who are seeking treatment for gynaecological disorders. Ovulatory disorders are common causes of sub-fertility and infertility in women of reproductive age. Twenty-five percentage of infertility has been attributed to anovulation or oligoovulation.

The world health organisation classifies disorders of ovulation into 3 groups-Group 1-Secondary to hypothalamic pituitary failure, group 2-Result of hypothalamic pituitary dysfunction and group 3Secondary to ovarian failure.

Group-2 disorders also include, women with hyperprolactinemia and unexplained anovulation.
Diagnostic test to document ovulation includes measurements of mid luteal serum progesterone and daily BBT. Obesity, Diabetes mellitus, thyroid disorders are some of the medical conditions causing anovulation or oligo-ovulation.

Among infertile females PCOS is the commonest endocrinological abnormality affecting $6.6-8 \%$ of women of reproductive age group. It is associated with $75 \%$ of cases of anovulatory infertility. ${ }^{2-4}$

Clomiphene citrate remains the most commonly prescribed ovulation inducing medication and is the most appropriate initial choice in largest majority of anovulatory infertile women. This drug was introduced in 1956. The first clinical trial of the clomiphene citrate therapy demonstrated successful ovulation induction in 
eighty percentage of women, half of whom achieved pregnancy during treatment itself. ${ }^{5}$

CC administration leads to depletion of oestrogen receptors at the level of the pituitary and hypothalamus, interrupting the negative feedback that oestrogen normally produces. As a result, GnRH secretion improves and stimulates pituitary production of $\mathrm{FSH}$, which in turn drives follicular growth and maturation with emergence of $\geq 1$ dominant follicle. ${ }^{6}$

The addition of an ovulatory dose of HCG has been used as an adjuvant to $\mathrm{CC}$ treatment to trigger ovulation. When size of pre-ovulatory follicle reaches to $16-25 \mathrm{~mm} .^{7-11} \mathrm{Inj}$. hCG has similar activity to $\mathrm{LH}$ and binds to its receptor. It is capable of inducing luteinisation and ovulation. Ovulation occurs 38-40 hours after a single HCG injection (10,000 IU IM).

Initial studies of the therapeutic potential of clomiphene citrate, conducted more than 40 years ago, focused on its adverse effects on fertility in animal models. In 1960, Kester and Smith performed the first clinical trials for ovulation induction in women. ${ }^{12}$ Soon afterward, Greenblatt and colleagues reported successful induction of ovulation in nearly $80 \%$ of a group of amenorrheicanovulatorywomen. ${ }^{13}$

Many gynaecologists use injection hCG routinely for triggering the rupture of follicle in $\mathrm{CC}$ induced cycle even though there is paucity of RCT's documenting the efficacy of this approach.

The study seeks to explore the utility of routine hCG trigger in $\mathrm{CC}$ induce cycle.

\section{Aims and objectives}

The present study, conducted in the department of obstetrics and gynaecology, LLRM medical college and associated SVBP hospital, Meerut with the following objectives and aims-to see the utility of human chorionic gonadotrophin (hCG) injection to enhance the rate of ovulation and pregnancy rate in cycle concerned, to compare the conception rate in hCG and non-hCG cycle and any other observation.

\section{METHODS}

\section{Place of study}

The study conducted in the department of obstetrics and gynecology, L.L.R.M. medical college, S.V.B.P. hospital Meerut, from June 2016 to May 2017.

\section{Study design}

The study design was experimental type of randomized controlled trial.

\section{Sample size}

In a study (Legro et al the live-birth rate was $22.5 \%$ (47 of 209 subjects) in the clomiphene group, $7.2 \%$ (15 of 208) in the metformin group. The sample size was calculated using the following formula (Charan et al).

$\mathrm{N}=2 \times\left(\mathrm{Z}_{\alpha / 2}+\mathrm{Z}_{\beta}\right)^{2} \times \mathrm{P}(1-\mathrm{P}) /(\mathrm{p} 1-\mathrm{p} 2)^{2}$

Where, N: Sample size per group p1: Prevalence in group 1, p2: Prevalence in group 2, P: Pooled prevalence $=(\mathrm{p} 1+\mathrm{p} 2) / 2$

$\mathrm{Z}_{\alpha / 2}$ : Significance level, $\mathrm{Z}_{\beta}$ : Power of the study.

Assuming $80 \%$ power, 5\% significance level with $95 \%$ confidence interval, the required sample size per group is 70 .

Cases were enrolled for the study with following inclusion and exclusion criteria.

Inclusion criteria were age - 20-40 years, duration of infertility $>1$ year, primary and secondary infertility with oligo/anovulation (bleeding interval between 35 days and 6 months) or amenorrhea (bleeding interval $>6$ months), normo-prolactinemia and normo-gonadotropic (WHO class 2 ovarian dysfunction) with normo-thyroid status, no history of ovulation induction treatment within 6 months, normal utero-tubal status and normal seminogram in husband, according to WHO criteria-

Table 1: WHO criteria.

\begin{tabular}{|ll|}
\hline Parameters & WHO 2010 \\
\hline Volume & $1.5 \mathrm{ml}$ \\
\hline Concentration & $15 \mathrm{million} / \mathrm{ml}$ \\
\hline Progressive motility & $32 \%$ \\
\hline Normal forms & $4 \%$ \\
\hline
\end{tabular}

\section{Methodology}

All infertile patients (anovulation/PCOD) attending the genie OPD of LLRM medical college, S.V.B.P hospital, Meerut are enrolled for the study. Clearance from ethical committee was taken.

Written and informed consent was taken from all cases for thesis participation. A detailed history (including age, occupation, menstrual cycle pattern, use of contraception, previous infection, coital frequency, history of infertility in family, previous infertility treatment, any surgery etc.) and thorough physical examination including height, weight, BMI, blood pressure, thyroid examination (for swelling), breast examination (for galactorrhoea), presence of marker of insulin resistance (Acanthosis nigricans, skin tag, W/H ratio), markers of hyperandrogenism (Hirsutism, acne) followed by genital examination will be done. All patients were advised for routine infertility investigations like hemogram, S. TSH, serum prolactin, Monteux test, HSA, 
HSG/Laparoscopy (if required), blood sugar (fasting and 2 hours after $75 \mathrm{~g}$ glucose). Patients were asked to come on day 2 or day 3 of menstrual cycle for complete biochemical/hormonal profile (S. LH, S.FSH, AMH and S. testosterone) and TVS for antral follicular count, ovarian volume, endometrial thickness and ruling out any other pelvic pathology.

Women who meet the inclusion criteria were allocated into two groups according to random number table with use of opaque envelope technique.

Group A-Women receiving clomiphene citrate alone and group B-Women receiving clomiphene citrate with inj. HCG (10,000 IU/IM) trigger when one or more follicles reach $20-22 \mathrm{~mm}$ in diameter, as determined by USG. All data were recorded on master chart and appropriate statistical tests were applied to see the significance.

\section{Statistical tools used}

The results are presented in frequencies, percentages and mean \pm SD. Chi-square test was used to compare the categorical variables. The unpaired t-test was used to compare the continuous variables between the groups. The $\mathrm{p}<0.05$ was considered significant. All the analysis was carried out on SPSS 16.0 version (Chicago, Inc., USA).

The statistical formulas used were: Mean, standard deviation, student ' $t$ ' test- to test the significance of two means, level of significance ("p" is level of significance)$\mathrm{p}>0.05$ not significant, $\mathrm{p}<0.05$ significant, $\mathrm{p}<0.01$ highly significant and $\mathrm{p}<0.001$ very highly significant.

\section{RESULTS}

Majority of the women in present study in both groups were of age between $25-30$ years (50\% in group A, 53\% in group B) but there was no statistically significant difference between the group $(\mathrm{p}=0.91)$. The mean age of patients of group A and group B were 26.19 \pm 3.96 and $26.50 \pm 4.02$ years respectively. There was no significant $(p>0.05)$ difference between the groups showing comparability in terms of parity, duration of marriage, duration and types of infertility (Table 2).

Abnormal no. of cycles was in about half of patients in both group A $(51.9 \%)$ and group B (50\%). Abnormal flow was in $42.3 \%$ of group A and in $51.6 \%$ of group B. Abnormal duration were in $34.6 \%$ in group A and in $50 \%$ of group B. Dysmenorrhea was present in $59.6 \%$ patients of group A and in $46.8 \%$ of group B. Dyspareunia was present in $40.4 \%$ patients of group $A$ and in $35.5 \%$ of group B. There was no significant $(\mathrm{p}>0.05)$ difference in menstrual history between the groups (Table 3 ).

There was no significant $(p>0.05)$ difference in anthropometric parameters and body habitus between the groups (Table 4). There was no significant ( $>>0.05)$ difference in the general examinations between the groups such as galactorrhoea, acne, hirsutism, thyroid and acanthosis nigricans.

LH/FSH (normal 1:1) was raised in $30.8 \%$ patients in group A and in $30.6 \%$ patients in group B. TSH was raised in $5.8 \%$ of group A and $8.1 \%$ of group B. There was no significant difference between the biochemical parameters between the groups (Table 5). There was no significant ( $>0.05$ ) difference in the ovarian volume, AFC, endometrial thickness between the groups.

Table 2: Distribution of patients according to age, parity, type of infertility, duration of marriage and duration of infertility between the groups.

\begin{tabular}{|c|c|c|c|c|c|}
\hline \multirow[t]{2}{*}{ Variables } & \multicolumn{2}{|c|}{$\begin{array}{l}\text { Group A, } \\
(\mathbf{n}=52)\end{array}$} & \multicolumn{2}{|c|}{$\begin{array}{l}\text { Group B, } \\
(\mathrm{n}=62)\end{array}$} & \multirow{2}{*}{$\begin{array}{l}\text { P } \\
\text { value }^{1}\end{array}$} \\
\hline & No. & $\%$ & No. & $\%$ & \\
\hline \multicolumn{6}{|l|}{ Age (years) } \\
\hline$<25$ & 18 & 34.6 & 21 & 33.9 & \multirow{3}{*}{0.91} \\
\hline $25-30$ & 26 & 50.0 & 33 & 53.2 & \\
\hline$>30$ & 8 & 15.4 & 8 & 12.9 & \\
\hline \multicolumn{6}{|l|}{ Parity } \\
\hline $\mathrm{P} 0$ & 35 & 67.3 & 41 & 66.1 & \multirow{3}{*}{0.56} \\
\hline $\mathrm{P} 1$ & 11 & 21.2 & 18 & 29.0 & \\
\hline $\mathrm{P} 2$ & 6 & 11.5 & 3 & 4.8 & \\
\hline \multicolumn{5}{|c|}{ Type of infertility } & \multirow{3}{*}{0.89} \\
\hline Primary & 25 & 48.1 & 29 & 46.8 & \\
\hline Secondary & 27 & 51.9 & 33 & 53.2 & \\
\hline $\begin{array}{l}\text { Duration } \\
\text { of } \\
\text { marriage } \\
(\text { Mean } \pm \text { SD) }\end{array}$ & \multicolumn{2}{|c|}{$5.22 \pm 3.79$} & \multicolumn{2}{|c|}{$6.19 \pm 3.08$} & 0.21 \\
\hline $\begin{array}{l}\text { Duration } \\
\text { of } \\
\text { infertility } \\
(\text { Mean } \pm \text { SD) }\end{array}$ & \multicolumn{2}{|c|}{$3.90 \pm 2.32$} & \multicolumn{2}{|c|}{$4.70 \pm 2.81$} & 0.06 \\
\hline
\end{tabular}

Table 3: Comparison of menstrual history.

\begin{tabular}{|c|c|c|c|c|c|}
\hline \multirow{2}{*}{$\begin{array}{l}\text { Menstrual } \\
\text { history }\end{array}$} & \multicolumn{2}{|c|}{$\begin{array}{l}\text { Group A, } \\
(\mathbf{n}=52)\end{array}$} & \multicolumn{2}{|c|}{$\begin{array}{l}\text { Group B, } \\
(\mathbf{n}=\mathbf{6 2})\end{array}$} & \multirow{2}{*}{$\begin{array}{l}\text { P } \\
\text { value }^{1}\end{array}$} \\
\hline & No. & $\%$ & No. & $\%$ & \\
\hline \multicolumn{6}{|c|}{ No. of cycles } \\
\hline Normal & 25 & 48.1 & 31 & 50.0 & \multirow{2}{*}{0.83} \\
\hline Abnormal & 27 & 51.9 & 31 & 50.0 & \\
\hline \multicolumn{6}{|l|}{ Flow } \\
\hline Normal & 30 & 57.7 & 30 & 48.4 & \multirow{2}{*}{0.32} \\
\hline Abnormal & 22 & 42.3 & 32 & 51.6 & \\
\hline \multicolumn{6}{|l|}{ Duration } \\
\hline Normal & 34 & 65.4 & 31 & 50.0 & \multirow{2}{*}{0.09} \\
\hline Abnormal & 18 & 34.6 & 31 & 50.0 & \\
\hline \multicolumn{6}{|c|}{ Dysmenorrhea } \\
\hline Absent & 21 & 40.4 & 33 & 53.2 & \multirow{2}{*}{0.17} \\
\hline Present & 31 & 59.6 & 29 & 46.8 & \\
\hline \multicolumn{6}{|c|}{ Dyspareunia } \\
\hline Absent & 31 & 59.6 & 40 & 64.5 & \multirow{2}{*}{0.59} \\
\hline Present & 21 & 40.4 & 22 & 35.5 & \\
\hline
\end{tabular}


Ovulation was found in $84.6 \%$ patients of group A (44 out of 52) and in $71 \%$ of group B (44 out of 62). Pregnancy was found in $20.5 \%$ patients of group A (9 out of 44) and in $31.5 \%$ of group B (14 out of 44). Abortion was found in $77.8 \%$ patients of group A (7 out of 9) and in $78.6 \%$ of group B (11 out of 14). There was no significant ( $\mathrm{p}>0.05)$ difference in the outcomes between the groups as shown in the Table 6.
Table 4: Comparison of anthropometric parameters.

\begin{tabular}{|llll|}
\hline $\begin{array}{l}\text { Anthropometric } \\
\text { parameters }\end{array}$ & Group A & Group B & $\begin{array}{l}\text { P } \\
\text { value }\end{array}$ \\
\hline BMI & $24.05 \pm 4.48$ & $24.66 \pm 4.77$ & 0.74 \\
\hline WC & $82.31 \pm 10.8$ & $85.52 \pm 11.3$ & 0.23 \\
\hline HC & $96.27 \pm 8.37$ & $97.00 \pm 9.34$ & 0.74 \\
\hline WHR & $0.84 \pm 0.06$ & $0.87 \pm 0.05$ & 0.06 \\
\hline
\end{tabular}

Table 5: Comparison of biochemical parameters between the groups.

\begin{tabular}{|c|c|c|c|c|c|}
\hline \multirow{2}{*}{ Variables } & \multicolumn{2}{|c|}{ Group A, $(n=52)$} & \multicolumn{2}{|c|}{ Group B, $(n=62)$} & \multirow{2}{*}{ P value $^{1}$} \\
\hline & No. & $\%$ & No. & $\%$ & \\
\hline \multicolumn{6}{|c|}{ LH/FSH ratio } \\
\hline Normal & 36 & 69.2 & 43 & 69.4 & \multirow{2}{*}{0.98} \\
\hline Raised & 16 & 30.8 & 19 & 30.6 & \\
\hline \multicolumn{6}{|l|}{ TSH } \\
\hline Normal & 49 & 94.2 & 57 & 91.9 & \multirow{2}{*}{0.63} \\
\hline Raised & 3 & 5.8 & 5 & 8.1 & \\
\hline \multicolumn{6}{|l|}{ Prolactin } \\
\hline Normal & 52 & 100.0 & 62 & 100.0 & \multirow{2}{*}{-} \\
\hline Raised & 0 & 0.0 & 0 & 0.0 & \\
\hline \multicolumn{6}{|c|}{ Blood sugar } \\
\hline Normal & 52 & 100.0 & 61 & 98.4 & \multirow{2}{*}{0.35} \\
\hline DM & 0 & 0.0 & 1 & 1.6 & \\
\hline
\end{tabular}

Table 6: Comparison of outcomes.

\begin{tabular}{|c|c|c|c|c|c|}
\hline Groups & Mature follicle & $\begin{array}{l}\text { Ruptured/unruptured } \\
\text { follicle }\end{array}$ & No. & Percentage (\%) & P value ${ }^{1}$ \\
\hline \multicolumn{6}{|l|}{ Group A, $(n=52)$} \\
\hline \multirow{2}{*}{$\begin{array}{l}\text { Clomiphene (up to } 100 \\
\mathrm{mg} \text { ) }\end{array}$} & \multirow{2}{*}{52} & Ruptured & 44 & 84.6 & \multirow{5}{*}{0.08} \\
\hline & & Unruptured & 8 & 15.4 & \\
\hline Group B, $(n=62)$ & & & & & \\
\hline \multirow{2}{*}{$\begin{array}{l}\text { Clomiphene (up to } 100 \\
\text { mg) + Inj. HCG }(10,000 \\
\text { IU/IM) }\end{array}$} & \multirow[b]{2}{*}{62} & Ruptured & 44 & 71.0 & \\
\hline & & Unruptured & 18 & 29.0 & \\
\hline Variables & \multicolumn{2}{|l|}{ Group A, $(n=44)$} & \multicolumn{2}{|c|}{ Group B, $(n=44)$} & $P$ value ${ }^{1}$ \\
\hline Pregnancy & No. & Percentage (\%) & No. & Percentage (\%) & \multirow{3}{*}{0.22} \\
\hline Yes & 9 & 20.5 & 14 & 31.8 & \\
\hline No & 35 & 79.5 & 30 & 68.2 & \\
\hline Abortion & \multicolumn{2}{|l|}{ Group A, $(n=9)$} & \multicolumn{2}{|c|}{ Group B, $(n=14)$} & $P$ value $^{1}$ \\
\hline Yes & 7 & 77.8 & 11 & 78.6 & \multirow{2}{*}{0.96} \\
\hline No & 2 & 22.2 & 3 & 21.4 & \\
\hline
\end{tabular}

\section{DISCUSSION}

Today, clomiphene citrate is safely used as ovulation inducing drug in patient of an anovulatory infertility, the recommended dose of clomiphene as per USFDA, initial dosage is $50 \mathrm{mg}$ daily for 5 days per cycle. The dose may be increased to $100 \mathrm{mg}$ daily $(2 \times 50 \mathrm{mg}$ tablets taken together as a single dose) for 5 days, per cycle if patients do not ovulate in response to $50 \mathrm{mg}$ daily. Although the prescribing information states that, dosages higher than $100 \mathrm{mg}$ daily are not recommended. Some clinicians continue to titrate up in $50 \mathrm{mg}$ increments until ovulation is achieved once the minimum effective dose has been determined, the patient may have attempted to conceive for 6-9 cycles. Some clinicians use inj. HCG routinely for triggering the rupture of follicle in clomiphene induced cycles. The present study seeks to explore the utility of routine HCG trigger in CC induced cycles.

The patients in the present study groups were given $\mathrm{CC}$ alone (group A) and CC with inj. HCG (10,000 IU/IM) and the ovulation rate in group A was $84.6 \%$ while that of group B was $71.08 \%$ ovulation rate of both groups were comparable with $\mathrm{p}=0.08 \quad(>0.05)$ So, there was no statistically significant difference between group A and B. 
Secondary outcome compared were that of pregnancy rate and abortion rate. Pregnancy occurred in $20.5 \%$ and $31.8 \%$ of patients in group $\mathrm{A}$ and group $\mathrm{B}$, respectively. The difference was statistically not significant as $\mathrm{p}=0.22$.

Continuation of pregnancy in group A and group B occurs in $22.2 \%$ and $21.4 \%$ respectively which were comparable with $\mathrm{p}=0.96(>0.05)$. So, there was no statistically significant difference between both groups.

Another study done by Robb et al, in which group A was given CC with inj. HCG 24 hrs prior to IUI and group B was given CC with inj. HCG $36 \mathrm{hrs}$ prior to IUI. ${ }^{15}$ No statistically significant difference in pregnancy rate $(\mathrm{p}=0.057)$, live birth $(\mathrm{p}=0.2)$ was seen.

Similar study conducted in Iran by Yilmaz et al; ovulation rate in both group A and group B were $75.4 \%$ and $83 \%$ respectively with $\mathrm{p}>0.05$ while pregnancy rate were $35 \%$ and $35 \%$ respectively with $\mathrm{p}>0.05 .^{15}$ Showing that difference of ovulation rate and pregnancy rate were statistically not significant.
Study done by Kyrou et al was a retrospective analysis to compare the efficacy of group $\mathrm{A}$ in which natural cycle with inj. HCG was given and in group B, CC with inj. ${ }^{16}$ $\mathrm{HCG}$ in normo-ovulatory patients undergoing frozen embryo transfer (FET) no significant difference in live birth was seen $(\mathrm{p}=0.708)$.

Another study conducted in Iran by Melli et al, is a RCT comparing the pregnancy rate among group A (with $\mathrm{CC}$ along with oxytocin $5 \mathrm{IU}$ ) and group $\mathrm{B}$ (with $\mathrm{CC}$ with inj. HCG $10,000 \mathrm{IU}){ }^{17}$ It was found that no statistically significant difference was present in ovulation rate of both groups with $\mathrm{p}>0.05$.

Study done in Fukuda et al is a prospective analysis, used inj. HCG trigger affect patient with productive ability during their subsequent cycle. ${ }^{18}$ It shows that $\mathrm{T} / \mathrm{T}$ with inj. HCG has the potential to influence not only the cycle during which it is administered but also in subsequent menstrual cycle (Table 7).

Table 7: Comparison of our study with various another research.

\begin{tabular}{|c|c|c|c|c|}
\hline Study & Type of design & Intervention & Results & P value \\
\hline Yilmaz (2006) & $\begin{array}{l}\text { Randomized } \\
\text { prospective study }\end{array}$ & $\begin{array}{l}\text { Group A }(n=65)- \\
\text { CC alone. } \\
\text { Group B }(n=60)- \\
\text { CC + inj. HCG }\end{array}$ & $\begin{array}{l}\text { No statistically significant } \\
\text { difference in ovulation and } \\
\text { pregnancy rate }\end{array}$ & $>0.05$ \\
\hline Robb et al (2004) & $\begin{array}{l}\text { Retrospective } \\
\text { study }\end{array}$ & $\begin{array}{l}\text { Group A-CC+ Inj. HCG } \\
24 \text { hrs. prior to IUI } \\
\text { Group B-CC+ Inj. HCG } \\
36 \text { hrs. prior to IUI }\end{array}$ & $\begin{array}{l}\text { No statistically significant } \\
\text { deference in pregnancy rate, } \\
\text { live birth }\end{array}$ & $\begin{array}{l}\text { PR }(p=0.057) \\
\text { Live birth } \\
(p=0.2)\end{array}$ \\
\hline $\begin{array}{l}\text { Melli et al } \\
(2006), \text { Iran }\end{array}$ & $\mathrm{RCT}$ & $\begin{array}{l}\text { Group A- CC+OT ( } 5 \\
\text { IU) } \\
\text { Group B- CC+ inj. hCG } \\
(10,000 \text { IU })\end{array}$ & $\begin{array}{l}\text { No statistically significant } \\
\text { deference in ovulation rate }\end{array}$ & $>0.05$ \\
\hline $\begin{array}{l}\text { Dimitra } \\
(2003)-(2006)\end{array}$ & $\begin{array}{l}\text { Retrospective } \\
\text { analysis }\end{array}$ & $\begin{array}{l}\text { To compare the efficacy } \\
\text { of group A-Natural } \\
\text { cycle + inj. HCG } \\
\text { Group B-CC+ inj. HCG } \\
\text { in normo-ovulatory } \\
\text { patients undergoing } \\
\text { frozen embryo transfer } \\
\text { (FET) }\end{array}$ & $\begin{array}{l}\text { No statistically significant } \\
\text { deference in live birth }\end{array}$ & 0.708 \\
\hline $\begin{array}{l}\text { Fukuda (2016) } \\
\text { Japan }\end{array}$ & $\begin{array}{l}\text { Prospective cohort } \\
\text { study }\end{array}$ & $\begin{array}{l}\text { Use of Inj. HCG trigger } \\
\text { affects patient's } \\
\text { reproductive ability } \\
\text { during their subsequent } \\
\text { menstrual cycle }\end{array}$ & $\begin{array}{l}\mathrm{T} / \mathrm{T} \text { with inj. hCG has the } \\
\text { potential to influence not } \\
\text { only the cycle during which } \\
\text { it is administered but also in } \\
\text { subsequent menstrual cycle }\end{array}$ & $\begin{array}{l}\text { Rate of } \\
\text { successful } \\
\text { Oocyte retrieval } \\
\mathrm{p}<0.001 \\
\text { Delivery rate } \\
0.002\end{array}$ \\
\hline Present study & $\begin{array}{l}\text { Experimental type } \\
\text { of randomized } \\
\text { controlled trial }\end{array}$ & $\begin{array}{l}\text { Group A-CC alone } \\
\text { Group B-CC+inj. HCG }\end{array}$ & $\begin{array}{l}\text { Outcome compared } \\
\text { ovulation rate, pregnancy } \\
\text { rate, abortion rate }\end{array}$ & $\begin{array}{l}\mathrm{P}>0.05 \\
\text { (statistically not } \\
\text { significant) }\end{array}$ \\
\hline
\end{tabular}

Limitation of my study was only that sometimes patients could not come for follow up in stipulated time, by which injection hCG timings became late.

\section{CONCLUSION}

Many gynaecologists use injection hCG routinely for triggering the rupture of follicle in $\mathrm{CC}$ induced cycle even 
though there is paucity of RCT's documenting the efficacy of this approach.

The present study concluded that routine addition of inj. HCG to CC ovulation induction therapy does not improve ovulation rate and pregnancy outcome. But because of very small sample size current inference of difference of ovulation and pregnancy cannot be made out, for meaningful results the study should include a large number of subjects with comparable demographics. At present there is a role of inj. HCG as a trigger for follicular rupture in absence of LH surge.

\section{Funding: No funding sources}

Conflict of interest: None declared

Ethical approval: The study was approved by the Institutional Ethics Committee

\section{REFERENCES}

1. World Health Organization. Recent advances in medically assisted conception. Report of a WHO Scientific Group. World Health Organ Tech Rep Ser. 1992;820:1-111.

2. Teide H, Deeks A, Moran L. Polycystic ovary syndrome: a complex condition with psychological, reproductive and metabolic manifestations that impacts on health across the lifespan. BMC Med. 2010;8(1):41.

3. Azziz R. Controversy in clinical endocrinology: diagnosis of polycystic ovarian syndrome: The Rotterdam criteria are premature. J Clin Endocrinol Metab. 2006;91(3):781-5.

4. Rotterdam ESHRE/ASRM-Sponsored PCOS Consensus Workshop Group. Revised 2003 consensus on diagnostic criteria and long-term health risks related to polycystic ovary syndrome (PCOS). Hum Reprod. 2004;19(1):41-7.

5. Kistner RW, Smith OW. Observations on use of nonsteroidal estrogen antagonist: MER 25. II. Effects in endometrial hyperplasia and Stein-Leventhal syndrome. Fertile sterile. 1991;12;121.

6. Schorge JO, Schaffer JI, Halvorson LM, Hoffman BL, Bradshaw KD, Cunningham FG. Treatment of the Infertile Couple. In: Schorge JO, Schaffer JI, Halvorson LM, Hoffman BL, Bradshaw KD, Cunningham FG, eds. Williams Gynecology. $1^{\text {st }}$ ed. New York, New York: McGraw-Hill Professional. 2008:450-51.

7. Management of infertility caused by ovulatory dysfunction. ACOG practice bulletin. Int J Gynecol Obstet. 2002;77:177-88.

8. Homburg $\mathrm{R}$, Insler $\mathrm{V}$. Ovulation induction in perspective. Hum Reprod Update. 2002;8:449-62.
9. Arici A, Byrd W, Bradshaw K, Kutteh WH, Marsh burn P, Carr BR. Evaluation of clomiphene citrate and human chorionic gonadotropin treatment: a prospective, randomized, crossover study during intrauterine insemination cycles. Fertil Steril. 1994;61:314-8.

10. Deaton JL, Clark R, Pittaway DE, Herbst P, Bauguess P. Clomiphene citrate ovulation induction in combination with a timed intrauterine insemination: the value of urinary luteinizing hormone versus human chorionic gonadotropin timing. Fertil Steril. 1997;68:43-7.

11. Zreik TG, Garcia-Velasco JA, Habboosh MS, Olive DL, Arici A. Prospective, randomized, crossover study to evaluate the benefit of human chorionic gonadotropin-timed versus urinary luteinizing hormone-timed intrauterine inseminations in clomiphene citrate stimulated treatment cycles. Fertil Steril. 1999;71:1070-4.

12. Kistner RW, Smith OW. Observations on use of nonsteroidal estrogen antagonist: MER 25. II. Effects in endometrial hyperplasia and Stein-Leventhal syndrome. Fertil Steril. 1961;12:121.

13. Greenblatt RB. Chemical induction of ovulation. Fertil Steril. 1961;12:402.

14. Robb P, Robins JC, Thomas MA. Timing of hCG administration does not affect pregnancy rates in couples undergoing intrauterine insemination using clomiphene citrate. JNMA. 2004;96(11):1431-3.

15. Yilmaz B. Addition of human Chorionic Gonadotrophin to clomiphene citrate ovulation induction therapy does not improve pregnancy outcomes and luteal function. Fertil Steril. 2006;85(3):783-6.

16. Kyrou D, Fatemi HM. Transfer of cryopreservedthawed embryos in hCG induced natural or clomiphene citrate cycles yields similar live birth rates in normo-ovulatory women. J Assist Reprod Genet. 2010;27:683-9.

17. Melli MS, Tagavi S. Comparision the effect of Oxytocin and Human Chorionic Gonadotrophin on ovulation. J Med Sci. 2007;7:1126-34.

18. Fukuda J. Administering human chorionic gonadotrophin injections for triggering follicle maturation could impact fertility during the subsequent menstrual cycle. Int J Gynecol Obstet. 2016;132(3):309-13.

Cite this article as: Verma A, Gupta A, Kashyap M, Meraj J. Conception rate with or without hCG trigger in clomiphene induced cycles. Int J Reprod Contracept Obstet Gynecol 2021;10:3142-7. 